\title{
Tenderizing property of Allium cepa and its effects on the proximate composition of Phaseolus vulgaris beans stew
}

\begin{abstract}
The present study sought to investigate the tenderizing property of Allium cepa (Onions) and its tendency to alter the proximate composition of Phaseolus vulgaris beans stew. Five hundred grams ( $500 \mathrm{~g}$ ) of beans sample was cooked with 20, 40, 60 and $80 \mathrm{~g}$ of $A$. серa after which twenty-one (21) persons evaluated the texture of the cooked whole beans using their thumb and index finger, and thereafter rated the degree of tenderness of each samples in comparison with the control sample. Proximate analysis was carried out on each of the samples before and after cooking. The data was analysed using Pearson chi-square tests and analyses of variance. The results showed that $60 \mathrm{~g}$ and $80 \mathrm{~g}$ of $A$. cepa caused significant $(\mathrm{p}<0.05)$ tenderization of $P$. Vulgaris beans. Furthermore, A. cepa caused increases in the moisture $(53.39 \%-57.01 \%)$, ash $(1.5 \%-2.85 \%)$, fibre $(0.25 \%-1.17 \%)$, fat $(5.07 \%-6.65 \%)$, protein $(17.99-9.94 \%)$ and carbohydrate $(21.39-22.39 \%)$ contents of P. vulgaris beans after cooking. The study showed that cooking $500 \mathrm{~g}$ of P. vulgaris beans with $A$. cepa $(>60 \mathrm{~g})$ caused significant $(\mathrm{p}<0.05)$ tenderization as well as altered the proximate composition of the beans.
\end{abstract}

Volume 6 Issue 5 - 2018

\section{Victor Duniya Sheneni,' Theophilus Boniface} Momoh, ${ }^{2}$ Emmanuel Edegbo ${ }^{3}$

'Department of Biochemistry, Kogi State University, Nigeria 2Department of Biological Sciences, Kogi State University, Nigeria

${ }^{3}$ Department of Microbiology, Kogi State University, Nigeria

Correspondence: Sheneni Victor Duniya, Department of Biochemistry, Faculty of Natural Sciences, Kogi State University, PMB 1008, Anyigba, Nigeria, Tel +234- 8033519009,

Email shinenivictor@gmail.com

Received: September 30, 2018 | Published: October 17, 2018

Keywords: Allium cepa, Phaseolus vulgaris, proximate composition

\section{Introduction}

Onion is an herbaceous biennial plant of the family Alliaceae or Liliaceae, which is grown for its edible bulb. Other members belonging to the same family include shallot (Allium cepa L. var. aggregatum G. Don.), common garlic (A. sativum L.), leek (A. ampeloprasum L. var. porrum L.) and chive (A. schoenoprasum L.). ${ }^{1}$ According to Hasegawa et al. 2001 onions originated from Central Asia, and cultivated in many countries around the world. In terms of income, onions are the second most important vegetable crop after tomatoes in the world. ${ }^{1,2}$ In South Africa, onions are considered to be the third most important vegetable crop after potatoes and tomatoes. ${ }^{3,4}$

The onion plants can reach a height of $50 \mathrm{~cm}$ and are grown as annuals, harvested after one growing season. A. cepa has fibrous roots (Ranjitkar, 2003); it is an underground stem modified into truncated bulb consisting of reduced stem and axillary buds surrounded by inner fleshy scale leaves and outer membranous dry scales (Ranjitkar, 2003). The stem is a flattened disc at the base of the plant and occurs below the soil surface. ${ }^{5}$ At the centre of the stem, new leaves and roots are produced. Each leaf is made up of a blade and sheath. It is the leaf sheath that appears to be the stem of the plant above the soil level. ${ }^{5}$ As the leaf sheath develops, it surrounds the growing point and forms a tube enclosing the young developing leaves. ${ }^{5}$

The proximate analysis of the two varieties of $A$. cepa revealed very high moisture contents, ranging from $82.99 \%$ in the Bangladeshi onion to $82.77 \%$ in the Indian onion. Calcium, phosphorus, sodium, potassium, iron and manganese were higher in the Bangladeshi variety of A. cepa. ${ }^{6}$ A. cepa provides flavour, colour and texture to a wide variety of dishes. But much more than the flavour, the health benefits of onion makes it highly significant in maintenance of human health and wellness. While onions are not particularly high in most nutrients, they contain anti-inflammatory, anti-cancer and antioxidant components such as quercetin. ${ }^{7}$ Fisetin, a flavonoid found in onion has a great role in treating chronic diseases. ${ }^{8}$ Onions are rich in vitamin $\mathrm{C}$ and chromium; a trace mineral involved to insulin response. ${ }^{7}$ Quercetin is known for its antibacterial and antioxidant activities. ${ }^{9}$

Phaseolus vulgaris is native to the New World, probably Central Mexico and Guatemala. The plant was taken to Europe by the Spaniards and Portuguese as well as Africa and other parts of the Old World. Now they are widely cultivated in the tropics, subtropics and temperate regions. Roughly $30 \%$ of world production is in Latin America. They are less known in India, where other pulses are preferred. ${ }^{10} P$. vulgaris is most widely cultivated of all beans in temperate regions, and widely cultivated in semitropical regions. In temperate regions, the green immature pods are cooked and eaten as a vegetable. Immature pods are marketed fresh, frozen or canned, whole, cut or French-cut (Adams, 1980). In lower latitudes, dry beans furnish a large portion of the protein needs of low and middle class families. ${ }^{10}$ In some parts of the tropics, the leaves are used as a potherb, and to a lesser extent the green-shelled beans are eaten. In Java, young leaves are eaten as salad. After beans are harvested, the straw is used for fodder. Beans have been reported to be used for cure for acne, bladder infection, burns, cardiac disorders, diabetes, diarrhea, dropsy, dysentery, eczema, emollient, hiccups, itch, kidney disorders, resolvent, rheumatism, sciatica, and tenesmus. ${ }^{11}$

The challenge associated with prolonged period required cooking and tenderizing the hard beans of P. vulgaris in Nigeria and all around the world. ${ }^{7}$ Previous study had shown that steak and tough meats soaked in onion juice before cooking became tender, hence reducing the cooking time and saving fuel for cooking. ${ }^{2}$ The present study sought to investigate the tenderizing property of $A$. cepa and its tendency to alter the proximate composition of $P$. vulgaris beans stew. 


\section{Materials and methods}

Study Area: The study was conducted in Anyigba, Dekina Local Government Area, Kogi State, North-Central Nigeria. The human population is estimated at 71, 327 according to National Census, 2006. Anyigba is located on Latitude 7'31" N and Longitude 1'12" E, with a total area of $11.07506 \mathrm{Sq} \mathrm{km} .{ }^{13}$ Anyigba is inhabited by Igala, Ebira and Bassa alongside people from other ethnic groups in Nigeria such the Yoruba, Igbo, Hausa, Idoma as well as foreign nationals. The climatic condition is tropical continental with distinct wet and dry seasons. The rainy season occurs between April and October and the dry season between November and April.

Collection and preparation of samples: The food items; beans, onions, fresh pepper and palm oil were purchased from the market in Anyigba (Unity square). A 500g of beans were measured into five different plastic containers and onion bulbs were peeled and sliced with a knife in a flat plate. Fresh pepper was also washed and homogenized using a manual blender. Increasing quantities $(20 \mathrm{~g}, 40 \mathrm{~g}, 60 \mathrm{~g}$ and $80 \mathrm{~g})$ of onions were measured using electric weighing balance (CAI-84) and transferred into beakers, which were appropriately labelled. The beans were washed with water and drained in sieves. The five stoves were arranged on the workbench and lit. Five pots containing 1.0L of water each were covered and arranged on the stoves and heated until the water boiled, after which the drained beans were introduced into each of the boiling water for all the five stoves. Increasing quantities $(20 \mathrm{~g}, 40 \mathrm{~g}, 60 \mathrm{~g}$, and $80 \mathrm{~g})$ of onions were introduced into the second, third, fourth and fifth pots respectively with no onion in the first pot (Control). Each cooking set-up was carefully labelled; control (0g), $20 \mathrm{~g}, 40 \mathrm{~g}, 60 \mathrm{~g}$ and $80 \mathrm{~g}$ of onions, respectively. Forty minutes later, $4 \mathrm{~g}$ of fresh pepper (Capsicum annuum), $4 \mathrm{~g}$ of seasoning cube (monosodium glutamate), $6 \mathrm{~g}$ of table salt and $10 \mathrm{ml}$ of palm oil were introduced into each of the five sets of cooking pots. Thereafter, the cooking pots were covered and allowed to cook for thirty more minutes after which the stoves were turned off.

Tenderizing effect: The same quantity of the food sample was put in five petri dishes in the order of quantity of onions added, $(0 \mathrm{~g}, 20 \mathrm{~g}$, $40 \mathrm{~g}, 60 \mathrm{~g}$ and $80 \mathrm{~g}$ ). Twenty one persons were made to feel the texture of each food sample using their thumbs and index fingers in comparison with the control sample. The respondents were then asked to rate the degree of tenderness of each sample in comparison with the control sample. The observations were scored as follows: no difference, moderate high difference. The total number of responses were analyzed and tabulated.

Proximate analysis: After cooling, samples were gotten from each of the five pots and put into plastic air-tight containers and further allowed to cool before refrigerating for seven hours. Proximate analysis was carried out according to the methods of Association of Official Analytical Chemist. ${ }^{14}$

Data analysis: The data were analysed using the Statistical Package for Social Sciences (SPSS) version 20. Pearson's chi-square test was used to ascertain the level of significance of each test, $p$-value was set at less than $0.05(\mathrm{p}<0.05)$.

\section{Results}

Table1 shows the result of comparison of tenderness carried out by twenty-one (21) persons between P. vulgaris cooked with $20 \mathrm{~g}$ and $0 \mathrm{~g}$ of $A$. сера. The result showed that there was no significant difference in the degree of tenderness between the control sample and the sample with $20 \mathrm{~g}$ of onion $\left(x^{2}=1.714\right.$, d.f $=2$, $\mathrm{p}$ value $\left.>0.05\right)$.
Table I Degree of tenderness between 20g and Control

\begin{tabular}{llll}
\hline Degree of effect & $\mathbf{2 0 g}$ & Control & Total \\
\hline No Difference & $7(33.3 \%)$ & $14(66.7 \%)$ & $21(100 \%)$ \\
Moderate Difference & $9(42.9 \%)$ & $12(57.1 \%)$ & \\
Much Difference & $5(23.8 \%)$ & $16(76.2 \%)$ & \\
Chi-square & 1.714 & & \\
d.f & 2 & & \\
P value & 0.424 & & \\
\hline
\end{tabular}

Table 2 shows the result of comparison of tenderness carried out by twenty-one (21) persons between P. vulgaris cooked with $40 \mathrm{~g}$ and $0 \mathrm{~g}$ of $A$. серa. The result showed that there was no significant difference in the degree of tenderness between the control sample and the sample with $40 \mathrm{~g}$ of onion $\left(x^{2}=5.143\right.$, d.f $=2$, $p$ value $\left.>0.05\right)$.

Table 2 Degree of tenderness between $40 \mathrm{~g}$ and control

\begin{tabular}{llll}
\hline Degree of effect & $\mathbf{4 0 g}$ & Control & Total \\
\hline No Difference & $5(23.8 \%)$ & $14(76 \%)$ & $2 \mathrm{I}(100 \%)$ \\
Moderate Difference & $\mathrm{II}(52.4 \%)$ & $10(47.6 \%)$ & \\
Much Difference & $5(23.8 \%)$ & $\mathrm{I} 4(76.2 \%)$ & \\
Chi-square & 5.143 & & \\
d.f & 2 & & \\
P value & 0.76 & & \\
\hline
\end{tabular}

Table 3 shows the result of comparison of tenderness carried out by twenty-one (21) persons between P. vulgaris cooked with $60 \mathrm{~g}$ and $0 \mathrm{~g}$ of $A$. cepa. The result showed that there was significant difference in the degree of tenderness between the control sample and the sample with $60 \mathrm{~g}$ of onion $\left(x^{2}=0.032, \mathrm{df}=2 \mathrm{p}\right.$ value $\left.<.05\right)$.

Table 3 Degree of tenderness between $60 \mathrm{~g}$ and control

\begin{tabular}{llll}
\hline Degree of effect & $\mathbf{6 0 g}$ & Control & Total \\
\hline No Difference & $3(14.3 \%)$ & $18(85.7 \%)$ & $2 \mathrm{I}$ \\
Moderate Difference & $\mathrm{I}(52.4 \%)$ & $10(47.6 \%)$ & \\
Much Difference & $7(33.3 \%)$ & $14(66.7 \%)$ & \\
Chi-square & 6.857 & & \\
d.f & 2 & & \\
P value & $0.032 *$ & & \\
\hline
\end{tabular}

Table 4 shows the result of comparison of tenderness carried out by twenty-one (21) persons between P. vulgaris cooked with $80 \mathrm{~g}$ and $0 \mathrm{~g}$ of $A$. cepa. The result showed that there was significant difference in the degree of tenderness between the control sample and the sample with $80 \mathrm{~g}$ of onion $\left(x^{2}=0.011\right.$, d.f $=2$, $\mathrm{p}$ value $\left.<0.05\right)$.

Table 4 Degree of tenderness between $80 \mathrm{~g}$ and control

\begin{tabular}{|c|c|c|c|}
\hline Degree of effect & $80 \mathrm{~g}$ & Control & Total \\
\hline No Difference & $6(28.6 \%)$ & & $21(100 \%)$ \\
\hline Moderate Difference & $12(57.1 \%)$ & & \\
\hline Much Difference & $3(14.3 \%)$ & & \\
\hline Chi-square & 9 & & \\
\hline d.f & 2 & & \\
\hline$P$ value & $0.011 *$ & & \\
\hline
\end{tabular}


The tenderizing effect of onion became significant and notable as the concentration of onions increased. In sample $20 \mathrm{~g}$, the onions had no tenderizing effect on the sample. The sample was not tendered than the control sample with $0 \mathrm{~g}$ of onion. With $40 \mathrm{~g}$ of onions, the effect on tenderness of the food sample was not significant whereas, there was significant difference in the level of tenderness of the samples that contain $60 \mathrm{~g}$ and $80 \mathrm{~g}$ of onions when compared with the control sample.

Table 5 shows the results of the proximate composition of cooked $P$. vulgaris samples with varied quantity of onions. The result showed that there was significant difference in the proximate composition of samples with increasing quantity of onions added to the cooking mixture; except for protein content of the beans which decreased following cooking $p$ value $<0.05$.

Table 5 Proximate composition of cooked $P$. vulgaris samples with varied quantity of onions

\begin{tabular}{|c|c|c|c|c|c|c|}
\hline Treatments & \% Moisture & Ash Content\% & Crude Fibre\% & Fat $\%$ & Protein \% & Carbohydrate \% \\
\hline Control & $53.39 \pm 0.02^{\mathrm{e}}$ & $1.53 \pm 0.03^{\mathrm{e}}$ & $0.25 \pm 0.05^{d}$ & $5.07 \pm 0.03^{\mathrm{e}}$ & $17.99 \pm 0.04^{\mathrm{a}}$ & $21.79 \pm 0.02^{b}$ \\
\hline $20 \mathrm{~g}$ & $56.05 \pm 0.05^{c}$ & $1.70 \pm 0.00^{d}$ & $0.52 \pm 0.02^{c}$ & $5.45 \pm 0.05^{d}$ & $17.06 \pm 0.00^{b}$ & $19.22 \pm 0.12^{d}$ \\
\hline $40 \mathrm{~g}$ & $56.40 \pm 0.00^{\mathrm{b}}$ & $2.15 \pm 0.05^{c}$ & $0.74 \pm 0.00^{\mathrm{b}}$ & $5.80 \pm 0.00^{c}$ & $14.57 \pm 0.04^{c}$ & $20.34 \pm 0.09^{c}$ \\
\hline $60 \mathrm{~g}$ & $56.87 \pm 0.07^{a}$ & $2.48 \pm 0.02^{\mathrm{b}}$ & $0.8 \mathrm{I} \pm 0.0 \mathrm{I}^{\mathrm{b}}$ & $6.17 \pm 0.03^{b}$ & $11.90 \pm 0.09^{d}$ & $21.78 \pm 0.10^{b}$ \\
\hline $80 \mathrm{~g}$ & $57.0 \mathrm{I} \pm 0.0 \mathrm{I}^{\mathrm{a}}$ & $2.85 \pm 0.05^{\mathrm{a}}$ & $1.17 \pm 0.03^{a}$ & $6.65 \pm 0.05^{\mathrm{a}}$ & $9.94 \pm 0.04^{\mathrm{e}}$ & $22.39 \pm 0.04^{a}$ \\
\hline Total & $55.94 \pm 0.44$ & $2.14 \pm 0.16$ & $0.70 \pm 0.10$ & $5.83 \pm 0.18$ & $\mid 4.29 \pm 1.01$ & $21.10 \pm 0.39$ \\
\hline
\end{tabular}

\section{Discussion}

The present study showed that onions have tenderizing effect on P. vulgaris. However, cooked $P$. vulgaris beans with relatively low quantity of onions showed no significant difference $(\mathrm{p}>0.05)$. This is in line with the report of Volhina, ${ }^{12}$ who noted that onions has a tenderizing effect on tough meat after soaking in onions juice before cooking.

Proximate analysis of the cooked $P$. vulgaris beans revealed a steady increase in most of the components of the beans stew samples except for protein component, which decreased with increase in the quantity of onions added. The reduction in protein concentration with increase in quantity of onions added in preparing the beans stew was probably as a result of presence of tannin and saponin in onions as previously reported. ${ }^{15}$ Tannins had been shown to possess protein binding capability, which appeared to suggest to being responsible for protein loss. ${ }^{16}$ Furthermore, tannins reduce maximum utilization of nutrients such as proteins, vitamins and minerals in animals. Some of these phytochemicals have been shown to be deleterious to health or evidentially advantageous to human and animal health if consumed. ${ }^{17}$ Anti-nutrients in plant foods are responsible for deleterious effects related to the absorption of nutrients and micronutrients. ${ }^{17}$ However, some anti-nutrients may exert beneficial health effects at low concentrations. For example phytic acid, tannins, saponins and protease inhibitors have been shown to reduce the availability of nutrients and cause growth inhibition. At low levels phytate, tannins, and saponins have also been shown to reduce the blood glucose and insulin responses to starchy foods and the plasma cholesterol and triglycerides. ${ }^{17}$ This implies that anti-nutrients might not always be harmful. Despite the result obtained from this study, the balance between beneficial and hazardous effects of plant bioactive principles and anti-nutrients rely on their concentration, chemical structure, time of exposure and interaction with other dietary components. As a result, they can be considered as anti-nutritional factors with negative effects or non-nutritive compounds with positive effects on health. ${ }^{18}$

There was a gradual increase in the ash content of the samples with increase in the quantity of onions added. The study of ash content provides an insight into the nutritionally important mineral elements which includes calcium, phosphorus, potassium, iron, sodium, zinc, manganese and copper. ${ }^{6}$ It was reported that the ash content of a food sample gives an idea of the mineral elements present in food. ${ }^{19,20}$

A steady increase in the fibre content as the quantity of onions increase in the food samples was noticed. Crude fibre is increasingly being recognized as a useful tool for the control of oxidative processes in food products and as functional food ingredient. The presence of crude fibre in the diet is necessary for digestion and for elimination of wastes. ${ }^{6}$ Crude fibre also functions in the protection against cardiovascular disease, colorectal cancer and obesity. Thus high consumption of onions in food is useful in the management of diabetes mellitus, colorectal cancers and weight reduction in obsessed individuals. ${ }^{6}$ The increase in carbohydrate and fat content noticed with increase in onions concentration in the food samples shows the significant role of onions in human health. This is in line with the work of Nwinuka et al. ${ }^{15}$ which showed that onions are a good source of carbohydrate.

\section{Conclusion}

The study provides evidence that $A$. cepa has a tenderizing effect on $\mathrm{P}$ vulgaris at relatively high quantity, thus validating the use of $A$. cepa as a tenderizing agent. Also the study showed that the proximate composition of beans was altered following cooking with A. cepa. The use of A. cepa as a tenderizing agent for Phaseolus vulgaris is recommended.

\section{Acknowledgements}

None.

\section{Conflicts of interest}

Author declares that there is none of the conflicts.

\section{References}

1. Griffiths GG, Trueman LT, Crowther TT, et al. Onions Global benefit to health. Phytotherapy Research. 2002;16(7): 603-615.

2. Mallor C, Balcells M, Mallor F, et al. Genetic variation for bulb size soluble solids content and pungency in the Spanish sweet onion variety Fuentes de Ebro. Response to selection for low pungency. Plant Breed. 2011;130(1):55-59. 
3. Department of Agriculture, Forestry and Fisheries. A profile of the South African onion market value chain. South Africa: University of Pretoria; 2012. p. 1-34.

4. National Agricultural Directory. Field crops and horticulture Vegetables. South Africa: Department of Agriculture, University of Pretoria; 2011.

5. Brewster JL. Onions and other Vegetable Alliums. 2nd ed. CABI. 2008 $432 \mathrm{p}$.

6. Shovon BS, Abida SA, Muhammad HS, et al. Analysis of the proximate composition and Energy values of two varieties of Onion: A Comparative Study. International Journal of Nutrition and Food Sciences. 2013;2(5):246-253.

7. George Matelijan Foundation (GMF). Onions: World's Healthiest Foods. 2007.

8. Pearlman RL, Pal HC, Afaq F. Advanced Experimental Medical Biology. A Handbook of medical Biology. 2016. p. 10-25.

9. Ramos AF, Yoshihisa T, Miki S, et al. Antibacterial and Antioxidant Activities of Quercetin Oxidation Products from Yellow Onion (Allium cepa) skin. Journal of Agricultural Food Chemistry. 2006;54(10):35513557.

10. CIAT. Bean production program; Annual Reports and assessing the nutritional value. 1974

11. James A Duke. Handbook of Energy Crops. 1999. p. 123-126.
12. Volhina J. Steaks marinated in onion juice. International Journal of Agricultural Food Chemistry. 2012;5(4):51-57.

13. Town Planning Development Board, Kogi State. Border regions and territoriality; changing significance, Regional Studies. 2002;33(7):593-604.

14. AOAC. Association of Official Analytical Chemists. Official methods of analysis $25^{\text {th }}$ ed. Arlington, VA. 2010.

15. Nwinuka NM, Ibeh GO, Ekeke GI. Proximate composition and levels of some toxicants in four commonly consumed spices. Journal of Applied Science and Environmental Management. 2005;9(1):150-155.

16. Dawra D, Rajinder K, Harinder PS, et al. Protein-binding capacity of microquantities of tannins. Analytical Biochemistry. 1988;170(1):50-53.

17. Ugwu FM, Oranye NA. Effects of some processing methods on the toxic components of African bread fruit (Treculia Africana). African Journal of Biotechnology. 2006;5(22):2329-2333.

18. Habtamu FG, Negussie R. Anti-nutritional factors in plant foods: potential health benefits and adverse effects. International Journal Nutrition Food Science. 2014;3(4):284-289.

19. Edeogu CO, Ezeonu FC, Okaka CN, et al. Proximate composition of staple food crops in Ebonyi State (South Eastern Nigeria), International Journal of Biotechnology and Biochemistry. 2007;3(1):1-8.

20. Kwenin WKJ, Wolli M, Dzomeku BM. Assessing the nutritional value of some African indigenous green Leafy Vegetables in Ghana. Journal of Animal and Plant Sciences. 2011;10(2):1300-1305. 